\title{
Moral dilemmas in professions of public trust and the assumptions of ethics of social consequences
}

\author{
Paulina Dubiel-Zielińska
}

\begin{abstract}
The aim of the article is to show the possibility of applying assumptions from ethics of social consequences when making decisions about actions, as well as in situations of moral dilemmas, by persons performing occupations of public trust on a daily basis. Reasoning in the article is analytical and synthetic. Article begins with an explanation of the basic concepts of "profession" and "the profession of public trust" and a manifestation of the difference between these terms. This is followed by a general description of professions of public trust. The area and definition of moral dilemmas is emphasized. Furthermore, representatives of professions belonging to them are listed. After a brief characterization of axiological foundations and the main assumptions of ethics of social consequences, actions according to Vasil Gluchman and Włodzimierz Galewicz are discussed and actions in line with ethics of social consequences are transferred to the practical domain. The article points out that actions in professional life are obligatory, impermissible, permissible, supererogatory and unmarked in the moral dimension. In the final part of the article an afterthought is included on how to solve moral dilemmas when in the position of a representative of the profession of public trust. The article concludes with a summary report containing the conclusions that stem from ethics of social consequences for professions of public trust, followed by short examples.
\end{abstract}

Keywords: profession, profession of public trust, moral dilemma, ethics of social consequences

\section{"Profession" and "profession of public trust" - definitional approach}

The concept of profession of public trust requires, firstly, an explanation of what a profession is. The term "profession" is ambiguous and does not have a legal definition (TaczkowskaOlszewska, 2014, p. 39), and in the social understanding it has different meanings. It is linked most often with elements such as qualifications, payment for services, their systematic nature and determining social position (Lazari-Pawłowska, 1971, p. 34). It is also an interdisciplinary concept, hence a number of psychological, economic, sociological, philosophical and pedagogical definitions. From an ethical point of view, a profession is an internally consistent system of activities aimed at the production of a product or services to meet specific needs. It is a "set of skills and associated knowledge and competence originating from specialization and social division of labor, performed continuously, periodically or casually. It is the primary source of income for individuals and their families" (Bittner \& Stępień, 2000, p. 44). Continuous performance of a profession shapes the personality of the employee and the way in which they function in society, creating distinct lifestyles and professional values and stereotypes. Representatives of particular professions are distinguished by: the type of operations performed, the conditions of work, professional competence, financial situation, position in society (Bittner \& Stępień, 2000, p. 50).

Half a century ago, Jan Szczepański included, in the factors influencing the profession and professional structure: a) system of internally consistent operations, based on specific knowledge and skills focused on the production of a certain object or services to meet widely understood needs; b) learned and using the necessary knowledge of activities performed by the employee regularly (periodically or permanently); c) the execution of these activities is the 
basis for economic existence of the worker, his maintenance and possibly his family; d) operations and related social consequences are the basis of prestige and social status of the employee (Szczepański, 1965, p. 16). The analysis of the proposed definitions in literature carried out at present by Urszula Jeruszka leads the author to conclude that "almost all definitions of profession emphasize the triple aspect of this concept: 1. relative stability of tasks and activities; 2 . the need to master the appropriate set of skills to perform these activities; 3. possibility of economic security of the worker and his family" (Jeruszka, 2010, p. 19).

It is certain that profession gives the right to a specific, recognized social activity, is an essential element of the services and benefits, rights and obligations, a complex of technical activities and the social role assigned to the profession. Continuous professional practice shapes the personality of the employee, his habits and behavior, creates professional families, different lifestyles, professional cultures, separate worlds and professional standards. Therefore, representatives of various professions differ in terms of professional technical operations, as well as due to the conditions of their employment, level of education, financial situation, interests, consumption, rights and responsibilities, roles and positions in society (Sarapata, 1965, pp. 144-145).

Profession of public trust, in turn, is somewhat a narrow meaning of the term "profession". It refers in fact to any profession "whose practice relates to the provision of certain services important from the point of view of a unit's basic goods - such as health, protecting the interests of property, personal property and others" (Młynarska-Sobaczewska, 2009, p. 740). On the other hand, according to Paweł Sarnecki, professions of public trust are "professions particularly desirable for the proper running of the whole of social life" (Sarnecki, 2001, p. 31). An inherent feature of professions of public trust is, therefore their performance to satisfy the public interest - not for profit. Occupation of public trust in a profession which relies on the use of personal human needs, which involves receiving information on personal life and is organized in a way that justifies the social belief of the right to use such information in the interests of the individual by the provider of service. Practice of a profession of public trust is further defined by the standards of professional ethics, a special oath, tradition of professional corporation or special nature of higher education and obtained specialization (application) (Sarnecki, 2000, pp. 149-163).

As the name indicates, "public trust" as an attribute of the profession means that all members of society will be able to hold legitimate expectations to the person performing a given public profession, as a guarantor of behavior consistent with applicable law (Czarnecki, 2013, p. 447). Representatives of professions of public trust guarantee therefore, that they will perform their duties to gain and develop trust, without the use of means and methods prohibited, within the rules of social conduct and professional ethics, even if these methods and tools guaranteed the success of their principals (Czarnecki, 2013, p. 446). The Constitutional Tribunal, referring to the doctrine, pointed out that the exercise of profession of public trust is associated with meeting high personal standards. According to judges it is justified by the fact that representatives of these professions are entrusted the duties of a special nature or particular importance from the point of view of the State's task, the concern for the realization of the public interest or the guarantee of freedom and individual rights (Wyrok Trybunału Konstytucyjnego z dnia 26 listopada 2003 r., pos. 26).

In the cited statements on public trust professions great emphasis is put on a unique, and therefore a strong need for their existence, conditioning the functioning of citizens, as well as on the uncommon nature of the qualifications, determining the performance of specific functions, centered around major areas of personal functioning of people using the services. Of the four characteristics of the profession, performed professional activities which are supposed to be marked by subtlety and care is specified as being an important issue . 
Representatives of public trust professions have access to sensitive data, information concerning the personal and even intimate life of others. Such work therefore requires awareness and sensitivity in the approach to another person.

\section{Characteristics and types of public trust professions}

The concept of professions of public trust is a specific feature of the Polish legal system, and it is not known in other countries in Europe. However, the concept of a liberal profession functions in legislation and European literature (Antkowiak, 2013, p. 135). In Poland, the definition of public trust profession was introduced by Article 17 of the Constitution of 2 April 1997, which binds professions of public trust with the existence of professional selfgovernment. Local governments must not infringe upon the freedom to practise a profession or limit the freedom to undertake economic activity. Organising a professional classified as a profession of public trust into a corporation means exercising it in a sense of public power; implementation of professional duties in an independent manner, based simply and solely on the provisions of the article; compulsory, by law, belonging to the corporation of all persons involved in that profession. Exercising custody by the local government over appropriately performed duties within the given professions understood in such a manner should be simultaneously implemented only within the limits of public interest and for its protection (Czarnecki, 2013, p. 447).

Professions of public trust include those that rely on performing tasks of exceptional character from the point of view of public tasks and care for the realization of the common interest (Konstytucja RP, 1997, Art. 17, item 1). The essence of these professions is providing some kind of help to other people, usually, but not only, in emergency situations, in order to achieve subjectively perceived benefit. This good is also considered to be good in the dimension of the general public, and serving to protect them is to carry out essential values and social needs. This includes among other aspects: care of health and life (doctors, pharmacists, psychologists, nurses, midwives), the protection of freedom (lawyers, legal advisers, judges), ensuring the security of legal transactions (notaries), security and infrastructure (architects, engineers, chartered accountants, insurance brokers, tax advisors, stockbrokers, investment advisors, accountants), protecting property (patent attorneys, property appraisers and certified translators) or even the formation of personality (journalists, pastors, teachers).

To the above mentioned we can add representatives of other professions, apart from the above-mentioned teachers, public officials (i.a., politician), and any uniformed professions (policemen, firemen, professional soldiers). Thus profession of public trust is a term common to the legal profession and related to the exercise of rights, medical and related professions resulting from the development of a market economy, professions related to the performance of duties in the construction and designing of space, uniformed professions associated with the establishment of free public media, public officials, clergy, etc. Performance of their professional duties in such cases comprises thus in exercising custody of managing affairs, or the protection of values (goods) of major significance for the people using this type of service. Resources (goods, values) of customers or patients at their disposal, to which they have access or come into the possession of, representatives of public trust professions are closely associated with the personality of a man, which are for example emotions, interpersonal relationship, ideas, intelectual resources, motives, doubts, attitudes, the needs of their clients or patients (Czarnecki, 2013, p. 446). This requires professional preparation, experience, discretion, tact and manners. Professions of public trust are implemented in a complex and publicly acceptable manner. This trust consists of belief about maintaining through professional good will, the right motivation, professional diligence and belief in respecting the 
values important for the profile of the profession (Kancelaria Senatu, Biuro Analiz i Dokumentacji, OT-625, 2013, p. 13).

Therefore, it takes a lot of discussion about ethical codes and the need for their existence. Regulations to standardize conduct of representatives of certain professions are implemented, increasing the efficiency and transparency of their work, safeguarding the interests of awakening professional awareness and knowledge of great complexity of social expectations, increasing the degree of identification with the profession (Kozakiewicz, 1971, pp. 153, 157) and - most importantly - the creation of support in not infrequent conflict situations (LazariPawłowska, 1971, p. 66). The rules of conduct have a not inconsiderable influence on disciplinary proceedings (Czarnecki, 2013, p. 447).

Representatives of professions of social trust saving human life and health, exercising power, providing expertise, establishing and enforcing the law, creating infrastructure - they are bestowed with enormous trust from the public. Awareness of this on both sides of contact raises a particular tension caused by the level of requirements. Not only that - the specifics of the aforementioned professions put them in the position of those whose actions are of general interest and decisions taken - because of their importance - reverberate and generate goodwill or hostility within society. This is, on the one hand elevating, because it adds prestige, accentuates the importance and rank of a given profession. On the other hand, it is destructive - sometimes leads to too much interest focus on the measures, their exaggeration and amplification, omitting the key issues. This gives rise to a kind of pressure. It is used by groups who are particularly interested and gain much from this. The important role of professional self-government, whose purpose is to regulate access to the profession, raise the prestige and professional status, control ethical behavior and care about the quality of the ranks, as well as protect against encroachment of executive power to influence local government self-regulation is indicated here (Czarnecki, 2013, p. 448).

\section{Moral dilemmas in professions of public trust}

People performing public trust professions cater to needs of the public, act on a person's behalf, they impose certain restrictions upon society. They therefore have a special kind of belief in the correctness of their judgments. All this for common good. However, there is a dark side to this reality, for when performing their duties they are uniquely vulnerable to dilemmas, such as a situation the solution to which requires a difficult choice between two different, equally important reasons, values, attitudes (Chyrowicz, 2008, p. 9). Such a choice is difficult, because the options are competitive, so opting for one of them does not seem entirely satisfactory. If you cannot choose both alternatives at the same time, there is something to gain and something also to be lost, someone to satisfy and someone to disappoint. The essence of the dilemma lies in the fact that the situation forces you to immediately take a position. An alternative may be a withdrawal from activities which in fact is a decision. The dilemma of a man stops halfway, calls for verification of the method of thinking and/or actions (Chyrowicz, 2008, pp. 9-10). There are moral and nonmoral dilemmas.

In a moral dilemma, both obligations (duties) have a moral dimension (Chyrowicz, 2008, p. 75). Barbara Chyrowicz formulates context definition (taking into account the context of the activities of the entity) of moral dilemma. By dilemma she understands "the situation in which the subject is convinced that he should $a$ and $b$ at the same time, and at the same time cannot fulfill the duties of $a$ without prejudice to the duties of $b$, or duties of $b$ without prejudice to the duties of $a$, with the duties of $a$ and $b$ (which can be both action and refraining from acting) are right on the basis of ethical theory, in which they attempt to resolve the dilemma" (Chyrowicz, 2008, p. 70). 
Moral dilemma ("impasse") is more dramatic than a nonmoral dilemma, because each of the alternatives of the action seems to indicate other good. Choosing a good one often means the loss of another. When the moment comes to choose, you realize that it is impossible to save everything, that the price to pay for your choice can be really high, and it is not easy to be confident that the choice is actually correct (Chyrowicz, 2008, p. 10).

For professions of public trust every moral dilemma they are faced with is a new situation. The hardship of struggle with it lies in the application of objective moral values to specific situations. Having formulated a general norm, they must refer it to the issue at hand for them. They should therefore make use of ethical theory, indicating the objective order of values and norms and subsequently their "interpretation" for specific use in a given situation (Chyrowicz, 2008, pp. 11-12). A reasonable proposal seems to be ethics of social consequences.

\section{Basic values, norms and actions in accordance with the ethics of social consequences}

Ethics of social consequences belongs to a group of non-utilitarian consequentialism theories. "Consequentialism is the general name given to the view, according to which the consequences of actions are morally important [...]" (Churchland, 2013, p. 283). Consequentialism supports the implementation of basic values (Gluchman, 2000, p. 53), as the proper response to them is to promote them. Modern consequentialism in its nonutilitarian form draws attention to something more than the utility of acts, emphasizing apart from the consequences - the weight of intention, and thus - issues of duty or the need to avoid actions and the fairness or wickedness of a given action. For example, ethics of social consequences evaluates simple deeds in the first place on the basis of the occurring consequences (because the consequences of actions are the main criterion for their moral value), followed by analyzing the intentions of the acting subject (in the case of simple activities which cause a prevalence of negative effects over positive). Intentions, which are the expected consequences (in other words: anticipated, likely), are the first criterion of evaluation of complex actions in terms of their duty or the need to avoid them. Another criterion is the actual (or: current) consequences. With regard to the assessment of fairness of acts, expected consequences are an equally important criterion as the real consequences. In non-utilitarian (classic) consequentialism, an action causing the maximum prevalence of positive over negative effects is mandatory, but when it is not feasible, it is recommended to strive to increase the volume or prevalence of positive over negative social consequences. Sometimes temporary, thus short-lived, predominance of negative effects over positive is correct if this contributes to the promotion of values. Moreover, consequentialism in its nonutilitarian form, in contrast to the classical model, introduces the plurality value, negating the sole value of pleasure. It contradicts the principle of impartiality.

The axiological basis of ethics of social consequences is created by the moral right to life (Gluchman, 2012a, p. 191 et al.). Moral law has a demanding and protective function. This demanding function concerns the promotion and development of life, and the protective function - its protection. The overriding values of the theory are human dignity (Gluchman, 2012a, p. 139 et al.) and humanity (Gluchman, 2012a, p. 123 et al.). Rights and obligations in relation to life result from humanitarianism. The other ethical values are accountability, justice, tolerance, responsibility. The notion of responsibility somehow regulates obligation. Liability of employee may be - in a negative sense - the consequence of his violation of duties, or - in a positive sense - having the required professional competence and conduct in accordance with applicable professional standards. The basic assumption of ethics of social consequences speaks of two kinds of obligation: 1) to strive in their daily efforts for a prevalence of positive over negative consequences; and 2) to follow, in one's own actions, certain rules. The basic rule is moral law. Moral law is one, but comes in many forms, depending on the community and culture. Moral laws are genetically, biologically, socially 
and culturally conditioned. They specify human dignity, they are an informal expression of moral values, while statutory rights are an institutionalized expression of some moral laws. Moral law is a frame, a form for the implementation of moral values, because the goal is not the law, but the realization of value (Gluchman, 2012a, p. 206).

In the ethics of social consequences - taking into account first of all the consequences, then intentions - Vasil Gluchman classifies actions as simple and complex. He evaluates simple actions - taking into account motivation as a secondary criterion - due to their effects. Intentions are taken into account in the case of causing a prevalence of positive over negative consequences and in the case of more complex actions (Gluchman, 2012a, p. 25).

Given the good intentions of the acting subject and the number of positive consequences Gluchman distinguishes the following actions: moral (causing a maximum prevalence of positive over negative consequences), right, namely appropriate (causing a specified, but not a maximum prevalence of positive over negative consequences) and wrong, that is inappropriate (causing a maximum or near maximum prevalence of negative over positive consequences). Considering the bad intentions of the person acting and a certain amount of effects, Vasil Gluchman lists the following actions: immoral (causing a considerable prevalence of negative over positive consequence), incorrect, or inappropriate (causing a specified, but not the maximum prevalence of positive over negative consequences or some, but not the maximum prevalence of positive over negative consequences) and right, or proper (causing a maximum prevalence of positive over negative consequences) (Gluchman, 2012a, pp. 24-30, 39).

Evaluation of more complex procedures in ethics of social consequences is two-fold. Firstly - it takes into account both the consequences and intentions, namely the likely (expected) consequences. Secondly - indicates compliance with the expected consequences of the real (probable) expectations, i.e. the suitableness of the act (Gluchman, 2012a, p. 44).

Valuation on the basis of the likely consequences is almost identical to the assessment on the basis of intentions. It is obvious that the likely positive consequences are based on good intentions and the likely negative consequences on bad intentions. Judging on the basis of the likely consequences is justified only in the sense of orientation in a certain stage of the proceedings, usually before it starts. Later, after initializing, a measure of its reasons drops (Gluchman, 2012a, p. 43). In the case of complex actions we formulate recommendations for obligation of (avoiding) the act in question (Gluchman, 2012a, pp. 33-40).

Due actions according to the ethics of social consequences are those actions that with the participation of good intentions are likely to result in a maximum or even minimum prevalence of positive over negative consequences. They are thus moral and righteous actions. Actions which should be avoided in ethics of social consequences are "actions based on bad intentions, whose aim is to bring in to a certain degree the likely prevalence of negative over positive consequences" (Gluchman, 2012a, p. 39). In these type of offenses we can include immoral and wrong (improper) acts. Wrong action (inappropriate, which with the participation of good intentions, results in a maximum or near maximum prevalence of negative over positive consequences), depending on the degree of reflection on the consequences before the act taken may be in effect rated as due - because the subject sufficiently learned the circumstances of the given action, or those which should be avoided because the subject relied solely on good intentions and did not appreciate the role of knowledge and analysis (Gluchman, 2012a, pp. 39-40).

An evaluation of complex actions, in which the compatibility of actual consequences with the expected is determined, which concerns the level of suitableness or unsuitableness of the action is presented as follows. Where there is actual compliance with probable consequences, actions are assessed as fair or wicked, and the coexistence of good intentions and positive actual or likely consequences means appropriate actions, and a combination of bad intentions 
and negative actual and likely consequences - wicked actions. Where there is no agreement between intentions and their likely or actual consequences, which is where the real consequences of the conflict are contrary to some extent with probable consequences, there we do not assess the action based on its fairness or wiskedness. With this contradiction we can mean either right or wrong behavior where the first case, the result of malicious intent/likely negative consequences are real positive consequences. In the second case, the result of good intentions/probable positive consequences are real negative consequences (Gluchman, 2012a, pp. 31-45).

What about useful and useless actions? According to the ethics of social consequences, intentions have no effect on the usefulness of the actions. You could even say that they interfere in deliberations on the usefulness of the actions. There arises thus the question of what to base the evaluation of the usefulness of action on. Only real social consequences have the impact on the utility of the action. The criterion for evaluation of usability or uselessness (harm) of the action, is a predominance of positive over negative social consequences or negative over positive (Gluchman, 2012a, pp. 47-49). Actions that are judged as moral and right (correct) because of good intentions and actions judged as wrong (inappropriate) or right (correct) because of bad intentions theactions are useful, while those that cause the maximum prevalence of positive effects over negative are more useful than those that cause a specified, or even a slight prevalence of positive consequences (Gluchman, 2012a, p. 54). Useless actions (harmful) achieve a prevalence of negative consequences over positive. These actions are fair with the participation of positive intentions and immoral actions are caused by bad motives. Simultaneously, we must also remember to take into account the presence of all consequences of the actions not only the dominant ones. Thus it must be assumed, depending on how great the prevalence of positive over negative or negative over positive consequences is, so is the measure of utility of righteous or wrong action (Gluchman, 2012a, pp. 54-55).

A diagram of actions according to ethics of social consequences is presented in the table below:

\begin{tabular}{|l|l|l|l|l|}
\hline \multicolumn{5}{|c|}{ Evaluation of complex action } \\
\hline $\begin{array}{l}\text { Evaluation of action by } \\
\text { consequence }\end{array}$ & $\begin{array}{l}\text { Consequences } \\
\text { for society } \\
\text { of action by } \\
\text { intentions (likely, } \\
\text { or expected } \\
\text { consequences) }\end{array}$ & $\begin{array}{l}\text { Intentions } \\
\text { fairness of } \\
\text { action } \\
\text { (compatibility } \\
\text { of real } \\
\text { consequences } \\
\text { with } \\
\text { expectations) }\end{array}$ \\
\hline $\begin{array}{l}\text { moral, } \\
\text { (useful: more useful) } \\
\text { current, } \\
\text { obligatory }\end{array}$ & $\begin{array}{l}\text { maximum } \\
\text { prevalence of } \\
\text { positive } \\
\text { consequences } \\
\text { over negative }\end{array}$ & Good & due & fair \\
\hline $\begin{array}{l}\text { right } \\
\text { (useful: less useful), } \\
\text { effective, obligatory, }\end{array}$ & $\begin{array}{l}\text { specified, but } \\
\text { not maximum } \\
\text { prevalence of } \\
\text { positive } \\
\text { consequences } \\
\text { over negative, }\end{array}$ & Good & due & fair \\
\hline
\end{tabular}




\begin{tabular}{|c|c|c|c|c|}
\hline $\begin{array}{l}\text { just } \\
\text { (useful: more useful) }\end{array}$ & $\begin{array}{l}\text { maximum } \\
\text { prevalence of } \\
\text { positive } \\
\text { consequences } \\
\text { over negative }\end{array}$ & $\mathrm{Bad}$ & should be avoided & $\begin{array}{l}\text { neither fair nor } \\
\text { wicked, but not } \\
\text { condemnable }\end{array}$ \\
\hline $\begin{array}{l}\text { unjust (useless, i.e. more } \\
\text { or less harmful- depending } \\
\text { on the number of negative } \\
\text { consequences) }\end{array}$ & $\begin{array}{l}\text { maximum or } \\
\text { near maximum } \\
\text { prevalence of } \\
\text { negative } \\
\text { consequences } \\
\text { over positive } \\
\text { (or exclusive } \\
\text { presence of } \\
\text { negative } \\
\text { consequences) }\end{array}$ & Good & $\begin{array}{l}\text { due (if the subject } \\
\text { has sufficiently } \\
\text { learnt the } \\
\text { circumstances of } \\
\text { the action) or one } \\
\text { which we should } \\
\text { avoid (if the } \\
\text { subject only relies } \\
\text { on good intentions } \\
\text { and does not } \\
\text { appreciate the role } \\
\text { of acknowledging } \\
\text { and analysis) }\end{array}$ & $\begin{array}{l}\text { neither fair nor } \\
\text { wisked, but not } \\
\text { condemnable }\end{array}$ \\
\hline $\begin{array}{l}\text { unjust } \\
\text { (useful: less useful), } \\
\text { impermissible }\end{array}$ & $\begin{array}{l}\text { specified, but } \\
\text { not maximum } \\
\text { prevalence of } \\
\text { positive over } \\
\text { negative } \\
\text { consequences }\end{array}$ & $\mathrm{Bad}$ & should be avoided & $\begin{array}{l}\text { wicked, but not } \\
\text { condemnable }\end{array}$ \\
\hline $\begin{array}{l}\text { unjust } \\
\text { (useless, i.e. more or less } \\
\text { harmful - depending on } \\
\text { the number of negative } \\
\text { consequences), } \\
\text { impermissible, }\end{array}$ & $\begin{array}{l}\text { specified, but } \\
\text { not maximum } \\
\text { prevalence of } \\
\text { negative over } \\
\text { positive } \\
\text { consequences }\end{array}$ & $\mathrm{Bad}$ & should be avoided & $\begin{array}{l}\text { wicked, } \\
\text { condemnable }\end{array}$ \\
\hline $\begin{array}{l}\text { amoral } \\
\text { (useless, i.e. more or less } \\
\text { harmful - depending on } \\
\text { the number of negative } \\
\text { consequences) } \\
\text { impermissible }\end{array}$ & $\begin{array}{l}\text { specified, but } \\
\text { not maximum } \\
\text { prevalence of } \\
\text { negative over } \\
\text { positive } \\
\text { consequences } \\
\text { (or exclusive } \\
\text { presence of } \\
\text { negative } \\
\text { consequences) }\end{array}$ & bad & should be avoided & $\begin{array}{l}\text { wicked, } \\
\text { condemnable }\end{array}$ \\
\hline
\end{tabular}

Table 1. Actions by ethics of social consequences; Source: own PD-Z

\section{Actions in accordance with ethics of social consequences - practical level}

Włodzimierz Galewicz distinguishes the following seven types of acts: obligatory, impermissible, permissible, neutral, supererogatory, within the limits of moral tolerance and unmarked (Galewicz, 2010, pp. 12-16). Social reality requires us to perform acts primarily prescribed and avoid impermissible acts. Obligatory actions are, in ethics of social consequences, included in the form of mandatory, due actions, or those that relate to a prevalence of positive over negative consequences. Such actions are moral and right. They also contain good intentions. Impermissible actions, in turn, are undue acts, based on bad intentions and anticipation of bad consequences. Such actions Vasil Gluchman refers to as "peak manifestation of inhumanity" (Gluchman, 2012a, p. 135). Located in this range are acts 
which result in the death of the innocent (acts of terrorism). Permissible actions (where each of at least two alternatives is equally good) are also, in ethics of social consequences, due acts. Neutral actions - which do not fit into a certain moral space - do not occur in ethics of social consequences. Supererogatory actions and those within the limits of moral tolerance are found in ethics of social consequences in the form of humanitarian acts, aimed at protection, defense, support for strangers, which go beyond moral obligation. Selfless help to a fellow human being can probably be considered as something more than a purely biological or natural dimension of human conduct. Since it is a manifestation of human behavior in relation to a man who goes beyond the natural dimension and is the result of cultural evolution and moral development (Gluchman, 2012a, pp. 105-106).

It is also about all kinds of activities based on selfless help that result from typical human reflexes: compassion towards suffering, the ability to forgive, care. Concern about all kinds of handicapped manifestations of human life occupies a unique position in ethics of social consequences (Gluchman, 2012a, pp. 110-111). Our natural duty, determined by biological, or social relations is the protection and support of people close to us. Providing protection and assistance to a foreigner, or a stranger is a pure reflection of our morality, bringing moral overvalue (Gluchman, 2012a, p. 121). Concern for the protection and development of our own lives can be assigned to a fundamental value of positive social implications equal to 1 . The more we move away from our biological or genetic line as a starting point to implement the idea of humanity, the more the value of positive social consequences of our behavior and conduct increases. Concern for the life of an offspring could be determined, for example, as 1.25, 1.5 for parents, in the case of relatives, depending on kinship from 1.75 to 2.5 , for friends and acquaintances from 3.0 to 5.0 and, in the case of realization of the idea of humanity towards foreigners and strangers, we could define concern at a range of values from 7.5 upwards, depending on the level of familiarity. The value of positive social consequences, in this case, depends even more on the extent of effort devoted to the protection, support and assistance of these people (Gluchman, 2012a, pp. 125-126).

Most importantly, we cannot realize the idea of humanity on the second level (protection of and help towards strangers) at the expense of realising humanity on the first level (protection of and help towards kin), because from a moral point of view, the priority is the implementation of humanity on the first level, and only after fulfilling at least minimally the idea of humanity and the formation of positive social consequences at this level can we deal with the consideration of methods for producing positive social consequences of the implementation of humanity on the second level (Gluchman, 2012a, p. 127). Through these activities man contributes to a new quality of social life. This makes it possible to speak ofuniversal humanitarianism (Gluchman, 2008, pp. 77-87). Actions unmarked in the moral dimension (difficult to decide: abortion, euthanasia) in ethics of social consequences are subjected to very detailed analysis. They relate to activities that have a decisive impact on the lives of others. Dilemmas arise from the fact that with a huge desire to limit human suffering (in a broad sense), taking any such decision is accompanied by widely understood human suffering. In addition, it is difficult to predict which decision would minimize this suffering. In such situations, Vasil Gluchman advises us to consider what the hopes and prognosis for the particular human life are to be at least to a minimum degree in terms of content similar to human life (Gluchman, 2012a, p. 103).

According to Gluchman, if human life, at least in the minimum extent is not similar in content to human life, then the protection or care of its maintenance is not a moral value because it exists only in a natural-biological form and we also have to approach it in this way. In the case of suffering, which is immense and does not augur well, help can also mean enabling this suffering to end. The necessity to support and protect life as a value occurs when it comes to life at least in the minimum extent corresponding to the qualitative criteria of 
human life. We should not extend the sufferings of human beings, and thus the suffering of their family. Of course, while maintaining at least a minimum level of health care (Gluchman, 2012a, pp. 129-131).

\section{Ethics of social consequences and moral dilemmas in professions of public trust}

Our daily duty, especially in professional life, in line with ethics of social consequences is such behaviour that allows you to achieve a prevalence of positive effects over negative (Gluchman, 2012a, p. 24). Rarely do we have to deal with simple, not very complex, situations where there is no need to choose, only the need to respond purely technically according to the requirement. We most often encounter situations of increasing complexity, requiring implementation of certain procedures. Then calculation in accordance with ethics of social consequences dictates to head for good intentions and deeply analyze, identify, organize the circumstances of the action in order to avoid unforeseen, negative consequences resulting in a prevalence of negative consequences over positive. Moral and right actions, which at the same time we assess as due, are conventional and therefore commanded. There are permitted acts where there is a choice of the possible equivalent of two or more alternatives. The choice between them is not very problematic because the expected consequences balance well. In professional life actions with the wrong motivation combined with the prediction of the consequences of bad conduct or immoral and wrong acts are impermissible. You should therefore avoid them. It is postulated in fact that one also takes into account the good of others, not just one's own. In the case of public trust professions, the above expectations take on a more extreme form of demanding that their representatives take into account in their work mostly someone else's good.

One also should not act with good intentions, but with no prior diagnosis of conditions and circumstances. One must be able to anticipate, though such capacity takes time, of course, with increasing experience. Supererogatory acts in the case of public trust professions are almost commonplace. Concern for strangers, the disabled, the sick, the injured; concern for human life, health and safety is quite characteristic of the profession. Hence great social expectations and emphasis on the intensified selection of candidates. Expectations applies mainly to moral predispositions.

In the case of professions of public trust, even being a righteous man, one encounters situations that require an individual to make difficult decisions. There are therefore moments, when basic goods and values are threatened - life, health. Then there is an enormous risk, because you have to make a decision not entirely consistent with our internal beliefs, our moral backbone. The act which we are supposed to undertake is an unmarked moral act, which is included in the category of so-called choosing lesser evil. These are the most common acts to minimize the number of negative consequences and even cause at the time a prevalence of negative consequences over positive, which in the long term prognosis increases positive over negative consequences. Actions of this kind were mentioned by Vasil Gluchman (Gluchman, 2012b, p. 50). In connection with consequences as one of the evaluation criteria in ethics of social consequences (as well as professional ethics based on this theory) it appears that the first and foremost thing is that recognizing and using the moral right to life, humanity, human dignity, responsibility, tolerance and obligation connect to the multiplying of positive consequences. Any behavior that promotes the protection, recognition and realization of these values has positive consequences, sometimes a prevalence of positive over negative consequences.

The model of reasoning and decision-making based on ethics of social consequences carries a message about the overriding objective of professional ethics, which is to protect, 
recognize and promote the moral right to life, its development and affirmation in all its manifestations, which connects to respecting and practising subsequent values of ethics of social consequences, namely humanity and human dignity. It is about the values that will define the basic nature of each professional ethics in all its areas (Gluchman, 2012b, pp. 5153). The aim of professional ethics is that representatives of the profession, company or institution by thinking and acting, help to protect, respect and realize the moral right to life (of a human), its development and affirmation as well as protecting, respecting and implementing human dignity in all its manifestations, at all levels of human relationships in a particular profession, company or institution. The employee has a duty in their work to take into account, protect and respect these values and principles. In a conflict between the values and principles based on the ethics of social consequences model of reasoning and decisionmaking, it obliges an individual to find the optimal solution that will bring about a prevalence of positive consequences over negative or minimize negative consequences (Gluchman, $2012 \mathrm{~b}$, pp. 53-57). The approach of ethics of social consequences, depending on the situation, allows the preference of the value of benefit, or quenching their thirst in action, that is choosing the alternative that will increase positive consequences (Gluchman, 2012b, pp. 5763).

Bringing us closer to answering the question about the way to make decisions regarding priorities in the situations of doubt Vasil Gluchman takes on the question of responsibility of employees. He believes that this responsibility can have a social dimension (liability of employees supporting the common good) and individual (employee's liability to a single customer). The liability of members of a particular profession can be further discussed at the macro-, micro- and mezzo social level. It is therefore an exterior surface. Another level of liability is the internal responsibility towards their profession, company or institution attributable to the workers. Both types of liability are complementary, which means that they have to be in equilibrium with each other. In the event of conflict between internal and external accountability assumptions, ethics of social consequences can be used, in which the value of humanity is in first place, then human dignity, followed by moral human rights. The values of justice, responsibility, tolerance and duty are secondary. The aim is to achieve a prevalence of positive consequences over negative, which does not mean that only maximizing the positive effects is considered to be good. Any prevalence of positive consequences over negative can be considered a good action. In certain circumstances, even a prevalence of negative consequences over positive may be appropriate (i. e. the theory of lesser evil) (Gluchman, 2012b, pp. 49-50).

What does this mean for a representative of a profession of public trust? In exceptional cases, so-called moral dilemmas, a situational approach should be recognized in the process of thinking, deciding and acting, sometimes assessment, which to the greatest extent will be compatible with universal ethical values, standards and principles, sometimes resulting in minimising negative consequences arising from a failure to respect them. Then a model of thinking, deciding and acting, sometimes of assessment is appropriate in accordance with ethics of social consequences, because it creates the space to consider the fundamental moral values, or principles, which would normally cause a prevalence of positive consequences over negative, and in exceptional cases - minimising negative consequences, according to the theory of lesser evil (Gluchman, 2012b, pp. 42-65; Gluchman, 2012c, p. 27). Here are a few examples. The first is a lawyer who has to carry out a transaction business (contract of purchase-sale of real estate in the center of a big city), and has come into possession of certain adverse information about his client (knowing he - in spite of making declarations - does not intend to extend the recreational park located on the area of interest, but to build modern office buildings). To increase the number of positive social consequences 
(for the welfare and health of the population) the lawyer should reveal this information and prevent certain oblique statements.

The second case is a doctor who in a dramatic situation has one life-saving vaccine, and can choose to give it to his son or an unfamiliar child, in line with the ethics of social consequences, he has the moral right to save his child. A third example is a firefighter who can save people in only one room during a fire, and there are a few rooms. In one there are three small children, their parents in the second and the third is a completely unfamiliar man to them, but, in fact, a brilliant doctor, who is on the verge of discovering a cure for cancer. According to the ethics of social consequences and the theory of the so-called lesser evil, the firefighter they must rescue the brilliant doctor, because it is likely that the discovery will bring more positive social consequences in the future and will save many lives. Examples could be multiplied, but those listed above seem to briefly illustrate decision-making in line with the ethics of social consequences.

\section{Conclusion}

Professions of public trust are characterized by: access to intimate, very personal information; existence of a relationship of trust; the need to maintain professional secrecy; strict rules on knowledge and skills; operation within the forms specified in the applicable legislation; lack of binding of those professionals with instructions regarding the content and methods of professional activity; definition of ethical principles; at times vows are required (Czarnecki, 2013, p. 453). Every day, according to ethics of social consequences, they should be guided by the principle of doing no harm to another person. In this case, it consists in not taking advantage of certain situations against another person, avoiding moral faux pas, not using their privileged position for their own selfish motives. Such behavior is a normal standard. Only in politics is it "above-standard" indicating humanitarianism (Gluchman, 2012a, p. 114). Ethics of social consequences additionally solves a number of moral dilemmas often encountered in professions of public trust. It makes it easy to answer the question about the choice between loyalty to one principle and avoiding negative consequences for unmarked actions in the moral dimension. Similarly it helps in cases of conflicts of interests and objectives where the expected results are not catastrophic but unfavorable for the acting subject (Gluchman, 2012a, pp. 114-115). Vasil Gluchman then recommends the principle of lesser evil, or minimizing losses. Although in situations with no way out, all are equal and have an equal right to protect (their own interests), should think long-term and be able to see the benefits of their decisions. It is necessary to draw attention, the good of which degree is at stake for each of the alternatives. In fact, it is not moral duties (standards) that are the subject of the conflict, but the needs of those involved in the dramatic situation (Chyrowicz, 2008, p. 354). Looking objectively, the majority option, which means operating by the principle of the greatest range of distribution of good which would be right, however, the degree of affinity takes centre stage.

Ethics of social consequences allows an individual to avoid guilt, because guilt does not necessarily indicate doing moral harm, but it indicates uncertainty. The model of professional ethics and the model of thinking based on this theory make justifying actions not an excuse but an explanation. An excuse is usually a form of confession, an explanation is usually associated with denial of guilt and declaring innocence (Austin, 1961, pp. 123-152). Each choice should be preceded by good motivation and made only based on specific, direct circumstances, or from rational possibility, in the light of the available knowledge of the likely consequences not only direct but above all delayed. These rules exist in ethics of social consequences, but do not actually forbid behavior which is not always ideal. They provide moral guidance, a kind of summary of the previous calculation. Therefore, a man who, in a 
difficult situation, is to make a choice refers to objective reality, ethics. This supports his moral decisions, but does not replace them.

Paulina Dubiel-Zielińska received her PhD degree at the Faculty of Arts of the University of Prešov and she is a teacher at the Nicolas Copernicus High School no IV in Rzeszów.

\section{Corresponding author:}

Paulina Dubiel-Zielińska, the Nicolas Copernicus High School no IV in Rzeszów, Dąbrowskiego 82, 35-036 Rzeszów (Poland)

email: paulina.d@op.pl

\section{References}

ANTKOWIAK, P. (2013): Polskie i europejskie standardy wykonywania wolnych zawodów [Polish and European Standards for Practicing of Liberal Professions]. In: Przeglad Politologiczny [Political Science Review], 18(1), pp. 129-142.

AUSTIN, J. L. (1961): A Plea for Excuses. In: J. O. Urmson \& G. J. Warnock (eds.): Philosophical Papers. Oxford: Oxford University Press, pp. 123-152.

BITTNER, B. \& STĘPIEŃ, J. (2000): Wprowadzenie do etyki zawodowej. Podręcznik [Introduction to Professional Ethics. Handbook]. Poznań: eMPi2.

CHURCHLAND, P. S. (2013): Moralność mózgu. Co neuronauka mówi o moralności [The Morality of the Brain: What Neuroscience Says on Morality], thumaczenie i przedmowa [trans. and preface by] M. Hohol, N. Marek. Kraków: Copernicus Center Press.

CHYROWICZ, B. (2008): O sytuacjach bez wyjścia w etyce. Dylematy moralne: ich natura, rodzaje i sposoby rozstrzygania [On Dead-end Situations in Ethics: Moral Dilemmas: Nature, Types and Ways to Resolve]. Kraków: Znak.

CZARNECKI, P. (2013): Postępowanie dyscyplinarne wobec osób wykonujacych prawnicze zawody zaufania publicznego [Disciplinary Procedure with Legal Professionals of Public Trust]. Warszawa: C.H. Beck.

GALEWICZ, W. (2010): W sprawie odrębności etyk zawodowych [On Separateness of Professional Ethics]. In: W. Galewicz (ed.): Moralność i profesjonalizm. Spór o pozycje etyk zawodowych [Morality and Professionalism: The Dispute over the Position of Professional Ethics]. Kraków: Universitas, pp. 9-119.

GLUCHMAN, V. (2000): Utilitarizmus a konzekvencializmus [Utilitarianism and consequentialism]. In: V. Gluchman \& M. Dokulil (eds.): Súčasné etické teórie. (Etika II) [Modern Ethics Theories: Ethics II]. Prešov: LIM, pp. 25-60.

GLUCHMAN, V. (2008): Etika a reflexie morálky [Ethics and Reflection of Morality]. Prešov: FF PU.

GLUCHMAN, V. (2012a): Etyka społecznych konsekwencji [Ethics of Social Consequences]. Warszawa: Wydawnictwo ISM i E „HUMANUM”.

GLUCHMAN, V. (2012b): Profesijná etika v kontexte konzekvencialistického uvažovania (ESD model profesijnej etiky) [Professional Ethics in the Context of Consequentialist Reasoning (ESC Model of Professional Ethics)]. In: V. Gluchman (ed.): Profesijná etika minulost' a pritomnost' [Professional Ethics - Past and Present]. Prešov: FF PU, pp. 42-65.

GLUCHMAN, V. (2012c): Analýza teoretických východísk profesijnej etiky na Slovensku [Analysis of the Theoretical Basis of Professional Ethics in Slovakia]. In: V. Gluchman et al.: Profesijná etika - analyza stavu profesijnej etiky na Slovensku [Professional Ethics - Analysis of the State of Professional Ethics in Slovakia]. Prešov: FF PU, pp. 11-52. 
JERUSZKA, U. (2010): Człowiek i zawód. Wybrane zagadnienia z pedagogiki pracy [Man and Profession: Chosen Issues od Pedagogy of Work]. Warszawa: IPISS - Instytut Pracy i Spraw Socjalnych.

KANCELARIA SENATU, BIURO ANALIZ I DOKUMENTACJI [CHANCELLERY OF THE SENATE, ANALYSES AND DOCUMENTATION OFFICE], OT-625, listopad [November] 2013, Zawody zaufania publicznego, zawody regulowane oraz wolne zawody. Geneza, funkcjonowanie $i$ aktualne problemy [Professions of Public Trust, Regulated Professions and the Liberal Professions. Origin, Functioning and Current Issues]. [online], [Retrieved: April 13, 2014]. Available at: http://www.senat.gov.pl/gfx/senat/pl/ senatopracowania/56/plik/ot-625_pdf.

KONSTYTUCJA RP [CONSTITUTION OF THE REPUBLIC OF POLAND]. [online], [Retrieved: April 13, 2014]. Available at: http://www.sejm.gov.pl/prawo/konst/polski/ kon1.htm.

KOZAKIEWICZ, M. (1971): Z problemów etyki zawodowej nauczyciela [Of the Problems of Professional Ethics of a Teacher]. In: A. Sarapata (ed.): Etyka zawodowa [Professional Ethics]. Warszawa: „Książka i wiedza”, pp. 150-173.

LAZARI-PAWŁOWSKA, I. (1971): Etyki zawodowe jako role społeczne [Professional Ethics as Social Roles]. In: A. Sarapata (ed.): Etyka zawodowa [Professional Ethics]. Warszawa: „Książka i wiedza”, pp. 33-73.

MŁYNARSKA-SOBACZEWSKA, A. (2009): Zawody zaufania publicznego [Professions of Public Trust]. In: W. Skrzydło, S. Grabowska \& R. Grabowski (eds.): Konstytucja Rzeczypospolitej Polskiej: komentarz encyklopedyczny [The Constitution of the Republic of Poland: Encyclopedic Commentary]. Warszawa: Wolters Kluwer, pp. 740-741.

SARAPATA, A. (1965): Zawód jako wyznacznik miejsca w społeczeństwie [Profession as a Determinant of a Place in the Society]. In: A. Sarapata (ed.): Socjologia zawodów [Sociology of Professions]. Warszawa: „Książka i Wiedza”, pp. 143-175.

SARNECKI, P. (2000): Pojęcie zawodu zaufania publicznego (art. 17 ust. 1 Konstytucji) na przykładzie adwokatury [The Concept of a Profession of Public Trust (Art. 17 paragraph. 1 of the Constitution) Exemplified by Advocacy]. In: L. Garlicki (ed.): Konstytucja-WyboryParlament. Studia ofiarowane Zdzisławowi Jaroszowi [Constitution-Elections-Parliament. A Study Dedicated to Zdzistaw Jarosz]. Warszawa: Liber, pp. 149-163.

SARNECKI, P. (2001): W sprawie znaczenia konstytucyjnego określenia „zawód zaufania publicznego" (art. 17 ust. 1 Konstytucji) [On the Meaning of Constitutional Term of „Professions of Public Trust" (Art. 17 paragraph. 1 of the Constitution)]. In: Ekspertyzy i Opinie Prawne. Biuletyn Biura Studiów i Ekspertyz Kancelarii Sejmu [Expertise and Legal Opinions: Newsletter of Bureau of Research of the Chancellery of the Sejm]. Warszawa: Wydawnictwo Sejmowe, 5(41)/00, pp. 28-33.

SZCZEPAŃSKI, J. (1965): Czynniki kształtujące zawód i strukturę zawodową [Factors Shaping Profession and Professional Structure]. In: A. Sarapata (ed.): Socjologia zawodów [Sociology of Professions]. Warszawa: „Książka i Wiedza”, pp. 11-22.

TACZKOWSKA-OLSZEWSKA, J. (2014): Przyszłość zawodu dziennikarza w Polsce wariantowe modele rozwiązań prawnych [The Future of the Profession of a Journalist in Poland - Variant Models of Legal Solutions]. In: Studia Medioznawcze [Media Studies], 58(3), pp. 39-50.

WYROK TRYBUNAŁU KONSTYTUCYJNEGO z dnia 26 listopada 2003 r., sygn. SK 22/02, OTK-A 2003/9/97 [THE DECISION OF THE CONSTITUTIONAL TRIBUNAL of 26 November 2003, Ref. SK 22/02, OTK-A 2003/9/97]. [online], [Retrieved: February 15, 2016]. Available at: http://otk.trybunal.gov.pl/orzeczenia/. 